UDC [316.444:37.091.212]-026.911-047.43

DOI 10.26697/9789669726094.2017.64

(C) Kozhevnikova A., 2017

Alina Kozhevnikova

Peter the Great St. Petersburg Polytechnic University

\title{
STUDENT MOBILITY: INSIDE VIEW
}

The student mobility is examined in this article. International education today is a way for cultural and knowledge sharing, self-development and deleting stereotypes. Adaptation and integration are the most important parts of the exchange study and it should be correctly organized by host country. The current state of psychology has been analyzed by establishing the meaning of intercultural communications and comparing two exchange studying experiences of the author in Europe (In Sweden and Czech Republic). There are pros and cons of exchange study systems established and particularly discussed step by step. More practical needs and availability of student mobility are also headlined.

Keywords: study, exchange, student mobility, intercultural, overview.

\section{Introduction}

Studying abroad is one of the best ways for sharing knowledge, building communications and getting experience. Every university has its own way of making intercultural communication, integrate incoming students, but there are common principles. I was an exchange student twice and I tried to complete an overview of such practice in this article.

\section{Materials and methods}

International educational ties today can be attributed to the most important and promising areas of international cultural exchange. To note that it can rightly be called one of the most dynamically connected aspects of cooperation since students and scientists are characterized by mobility, the desire to acquire new knowledge [2].

Modern international migration has a strong result, it adjusts the life of both the host community and the donor, influences the policies pursued by sovereign states, the relations between individual social groups within the recipient countries, and also changes the personal characteristics [3].

A positive attitude towards the representatives of another culture is also connected with such phenomena as adaptation and integration. 


\section{Psychological and pedagogical problems of modern specialist formation}

Adaptation is associated with the desire of a person to adapt to the conditions of another culture, without fundamentally changing their identity, preserving their traditions, moral and ethical values.

A deeper penetration and comprehension of another culture is associated with integration. Integration into another culture and cultural environment is conditioned by certain living conditions and is possible when the individual lives in another environment long enough.

The advantages of cooperation in higher education are obvious: it is the pooling of resources, especially when they are so inaccessible as now; Eliminates duplication and unnecessary copying of research topics; Better identification of projects and increasing confidence in their feasibility in a collective supervisory environment [1].

\section{Results}

The first exchange experience was in Umea, Sweden. The second one was in Prague, Czech Republic, and I want to headline four positive points with some comparing:

1. Good supporting team (or buddy program), where you can find help for day-to-day life.

In Umea there were teams made of 15 students each. A team was constant for all of the competitions. Additionally, teams made their meetings.

In Prague there were personal buddies for every exchange student. This is good for the first days and accommodation questions, but many buddies are lost after a couple of weeks. Hence, the first approach is better in accordance with human nature.

2. Clear document system, which you can easily complete even on foreign language.

Step to step system, moodle and rewriting of information helps to be ready with all documents in time and be in touch with every happening. country.

3. Wide cultural programs, which helps to assimilate at a new

Excursions, games and language classes (Czech), dancing classes (Sweden) become a good activity and intercultural diving.

4. High level of education and opportunities for studying different fields.

Mixing your field of study with a couple of other additional courses lets to get more experience.

At the same time I can add missed zones:

1. Scientific coaching. It would be more effective for students to keep in touch with a supervisor, who will coordinate with conferences, laboratories and everything concerning field of study. 

country.

2. Working on real projects or make a practice on real job in the

3. It should be an easier way to participate in a short-term including education program for every country.

\section{Discussion and conclusions}

Student mobility system is a perspective way for better education, but it should be more practical and available. Wider cultural experience, duplication of events and stuff helps to build stronger integration into a host country.

\section{References}

1. Astafieva, L. S. (2009). Mezhdunarodnyye obrazovatelnyye obmeny: istoriya i sovremennoye znacheniye [International educational exchanges: history and contemporary significance]. Bulletin of Peoples' Friendship University of Russia, 3, 40-46. (in Russian)

2. Bogolyubova, N. M., \& Nikolaeva, Ju. V. (2009). Mezhkulturnaya kommunikatsiya $i$ mezhdunarodnyy kulturnyy obmen [Intercultural communication and international cultural exchange]. Saint Petersburg: $\mathrm{SPbKO}$. (in Russian)

3. Ryazantsev, S. V., \& Grebenyuk, A. A. (2014). "Nashi» za granitsey. Russkiye, rossiyane, russkogovoryashchiye, sootechestvenniki: rasseleniye, integratsiya $i$ vozvratnaya migratsiya $v$ Rossiyu [ OUr» abroad. Russians, Russian-speakers, compatriots: resettlement, integration and return migration to Russia]. Moscow: ISPI RAS. (in Russian)

\section{Аліна Кожевнікова. Студентська мобільність: внутрішній перегляд.}

У иій статті розглядається мобільність студентів. Міжнародна освіта сьогодні $\epsilon$ способом обміну культурами та знаннями, саморозвитку та стирання стереотипів. Адаптація та інтеграчія ие найважливіші частини дослідження обміну. Поточний стан психології було проаналізовано шляхом встановлення значення міжкультурної комунікації та порівняння двох обмінних досліджень автора в Свропі (у Швеції та Чехії). С плюси і мінуси систем обміну. Більш практичні потреби та наявність мобільності студентів також орієнтовані.

Ключові слова: навчання, обмін, студентська мобільність, міжкультурний, загальний огляд. 


\section{Psychological and pedagogical problems of modern specialist formation}

Alina Kozhevnikova. Mobilność studentów: wymiar zewnętrzny. $W$ niniejszym artykule omawiana jest mobilność studentów. Obecnie edukacja międzynarodowa jest skutecznym sposobem poznawania obcej kultury $i$ zdobywania wiedzy, pomaga $w$ samorozwoju $i$ eliminowaniu stereotypów. Adaptacja $i$ integracja sa najważniejszymi elementami wymiany studentów. Aktualny stan psychologii zostat przeanalizowany poprzez określenie znaczenia komunikacji międzykulturowej $i$ przez porównanie dwóch badań dotyczących wymiany autora w Europie (Szwecji $i$ Czechach). Sa plusy $i$ minusy systemów wymiany. Sa również uprawnienia do tworzenia dostepności praktycznych potrzeb $i$ mobilności studentów.

Slowa kluczowe: studia, wymiana, mobilność studentów, międzykulturowe, przeglad.

Information about the author:

Kozhevnikova Alina - Master Student, Peter the Great St. Petersburg Polytechnic University. 